2021 TheoLogica

An International Journal for Philosophy of Religion and Philosophical Theology

S. I. THEOLOGICAL EXPLORATIONS IN TIME AND SPACE

DOI: https://doi.org/10.14428/thl.v5i1.31723

\title{
Eternity, Relative Realities, and Ontological Idealism About Time
}

\author{
MATYÁŠ MORAVEC \\ University of Cambridge \\ matyas.moravec@cantab.net
}

\begin{abstract}
This paper argues that idealism can offer a new solution to the problem of relating the "static" presence of things to eternity and the "dynamic" passage of reality in the temporal realm. I first offer a presentation of this problem using the dispute between Aquinas and Scotus, then describe "ontological idealism about time," as a smaller-scale idealism, and show how it resolves the original problem. I conclude by demonstrating that this view is consonant with the recent emphasis on the ontological dependence of things on God and that it offers a way of bringing together non-eternalist ontologies and the ontological conclusions posited by the special theory of relativity.
\end{abstract}

Keywords: Idealism, Scotus, Aquinas, Temporal ontology, Creation

\section{Introduction}

The aim of my paper is to revisit the debate about the relation between time and eternity as it has been formulated in Aquinas and Scotus. I argue that idealism can offer a new solution to the problem that this debate raises, namely, an apparent conflict between presentism required for becoming in the temporal realm and eternalism required for the presence of things to God (and hence omniscience) in eternity. I conclude by demonstrating that my solution is deeply consonant not only with some claims of the original medieval discussion but also with the recent focus on divine "causal knowledge" in philosophy of religion and the implications of the special theory of relativity.

\section{Aquinas and Scotus}

The root of the conflict between Aquinas and Scotus, which persists in different forms in contemporary analytic philosophy of religion, is roughly the following: on the one hand, the scholastics seem to assume, for the most part, what looks like a presentist ontology which says that only present events exist. (Mullins 2016, 74-86; Pasnau 2011, 389). On the other hand, they affirm that all things are somehow present to eternity where they exist "all at once," tota simul, which seems to require eternalism. This is because eternalism says that past, present, 
and future events exist. And these, in turn, all have to exist to satisfy the scholastic requirement for divine omniscience to include God's knowledge of the past, present, and future.

We can begin to see this tension by closely examining Aquinas' appeal to two famous metaphors: the first, of his own making, is that of the relation between the circumference of the circle and its centre as a tool to elucidate the relation between time and eternity. Aquinas writes:

Let us consider a determined point on the circumference of a circle. Although it is indivisible, it does not co-exist simultaneously with any other point as to position, since it is the order of position that produces the continuity of the circumference. On the other hand, the center of the circle, which is no part of the circumference, is directly opposed to any given determinate point on the circumference. Hence, whatever is found in any part of time coexists with what is eternal as being present to it, although with respect to some other time it be past or future ... The divine intellect, therefore, sees in the whole of its eternity, as being present to it, whatever takes place through the whole course of time. (Aquinas 1975a, I.66.7; see also Shanley 1997, 198; de Finance 1956, 28; Stump and Kretzmann 1981, 441)

The second metaphor appealed to by Aquinas, one that he took over from Boethius' Consolation of Philosophy, is that of an observer standing on top of a mountain (Aquinas 1980, 1:Id38Q1a5; 2003, Q16a7; 1964, 4. Knowledge in God (Ia.14-18):IaQ14a13). Boethius says that God "looks forward on all things as though from the highest peak of the world." (Boethius 1973, Book V, Prose 6, 427) Whereas humans may be likened to travellers who travel through a valley and see various sections of the road one step after another, God sees the entirety of the road from the peak of eternity, quasi ab aeternitatis specula (Aquinas 1952, Q2a12).

These two metaphors conjointly create tension. Although we may not need go as far as Brian Leftow who takes Aquinas to be something like a proto-A-theorist of time (Leftow 1990, 388), Aquinas does seem to hold a view of time that would now be most closely associated with presentism. On the other hand, however, the commitment to the "presence" (however defined) of things to eternity, elucidated by the circle metaphor from above, seems to cohere best with a tenseless theory of time (see Craig 1985, 478; Mellor 1986). We also cannot evade this problem by taking the "presence" of things merely in the epistemic sense, ${ }^{1}$

\footnotetext{
${ }^{1}$ It is worth pointing out that Mullins' insistence that "it is not clear that anyone prior to the nineteenth century actually held the view that all times are literally present to God" (Mullins 2016, 84) does not appear to be correct; one may disagree with de Finance about his ascription of the belief in "objective presence" (présence objective) of things to eternity to Aquinas, but it is difficult to not to read in this way the views that he ascribes to Peter John Olivi (de Finance 1956,
} 
since in various places, Aquinas requires absolute, literal presence of things in eternity to uphold divine knowledge of particulars (Craig 1985, 480). ${ }^{2}$ Knowledge is factive-and "truth supervenes on existence." (Johnson 2009, 439) God cannot know things that do not exist: the truthmakers for divine knowledge have to exist for that knowledge to exist too. Once again, we need not go as far as Craig to argue that Aquinas was a proto-B-theorist, but it is difficult to imagine how the presence of things in eternity squares with a presentist picture of time. One struggles to escape either of these conclusions in particular when analysing the pedagogical tools of the top of the mountain and the circumference of the circle. Observe that whereas the road that the traveller walks on may be accessible from the top of the mountain, the individual steps of the traveller are still successive (Padgett 2011, 122). Similarly, Aquinas' metaphor of the circle relies on the circle having been drawn, not being drawn (Shanley 1997, 202) - if all of its points exist on

35). All things considered, however, the problem is not as straightforward as it might initially seem: although the rough opposition between, on the one hand, "epistemic," or "objective" types of presence (i.e., things' being present to God in virtue of their being known by Him, for example, in their causes or as ideas) and "real," "physical" or "literal" presence (i.e., things being somehow "coexistent with / next to / in" eternity) is clear enough, it seems much more difficult to elucidate what the more nuanced difference between "physical" (Suarez, according to de Finance), "real" (Olivi and perhaps Aquinas) and "literal" (Mullins) presence is supposed to be. This terminological conundrum is even more aggravated by the examples that Aquinas himself uses. To give just one example, in the Commentary on the Sentences (Aquinas 1980, 1:Id38Q1a1), he says that divine knowledge of successive contingent things may be likened to five men who, successively, observe five contingent events. Intuitively, we should understand the presence of these individual contingent things to the five individual men as all of the above ("literal," "objective," "real," "physical," and "epistemic"). Unfortunately, our intuitions fail us when we try to picture the presence of these things once the five men's views are "fused" to create a picture of the way that all successive things are equally "present" to God. This is also due to the fact that, if omniscience conceived in terms of perfect knowledge of causes or as ideas is unavailable to us, finding a picture of things' "real" presence to someone's knowledge without appealing to their usual ontological reality is rather difficult. Mullins' claim that "[w]hen the Christian tradition says that all moments are present to God in eternity - at least with regard to God's omniscienceit is not meant to say something about the ontology of time. Rather it is saying something about God's mode of cognition" (Mullins 2016, 86) does not help us here. Whatever anyone meant to say is rather different from the question of what metaphysical presuppositions were required or should have been recognised as being required to say that; unless we can come up with a picture of epistemic presence that does not require something like a real or physical presence of the garden variety (without adopting the views of things known in their causes or as ideas that Aquinas rejects), Aquinas's authentic position remains a dead-end. For a detailed discussion of the problem involved in working out what this "presence" means, see (Goris 2005, 110-11).

${ }^{2}$ See Aquinas in Compendium Theologiae: "Even before [things] come to be, He sees them as they are actual in their existing [intuetur ea prout sunt actu in suo esse], and not only as they are future things and in their causes virtually, as we can know some future things. Contingent things, as future things existing virtually in their causes, are not determined to one thing, so that we can have certain knowledge of them. But as actual in their existing, they are now determined to one thing, and we can have certain knowledge of them." (Aquinas 2009, I.133) 
a par (as they do in a circle), then it cannot serve as a useful analogy for points of time which, at least according to medieval presentists, do not all exist on a par. And, if the circle is merely in the process of being drawn (as a schoolchild draws a circle with a compass), then they are not all "yet" present to eternity.

It is precisely the circle metaphor that forms the springboard for Scotus' critique of the "real" or "literal" presence of things to God (de Finance 1956, 35; Scotus 1963, 4:d38 part 2 and d39 Q1-5, [35]). Scotus' point is rather simple but powerful. As Shanley summarises it: "(1) only what actually exists can be present to God and (2) only the temporal present actually exists." (Shanley 1997, 200) Since "coexistence presupposes existence," things cannot coexist with God in eternity if they do not yet exist or anymore exist (de Finance 1956, 36-37). This problem is particularly difficult to deal with for Aquinas since the appeal to the presence qua divine ideas is one he rejected (de Finance 1956, 37). ${ }^{3}$

In short, however we try to get out of this conundrum, we seem to run into contradictions. Either we posit an eternity to which the entire temporal realm is present, which commits us to eternalism about time. Or we posit presentism, but this entails that not all things are present to eternity, which threatens divine omniscience. This conundrum is connected to another problem: how can we reconcile the human "dynamic" experience of temporal passage (and the property of "presentness" which it entails) with God's eternal "static" relation to events?

\section{Idealism}

Despite the fact that many theists in the history of philosophy held an idealist position about reality (Berkeley providing the best example), contemporary analytic philosophy of religion has almost entirely neglected an exploration of idealism as a serious option for its methodology. ${ }^{4}$ The reason for this does not lie so much with the association of different flavours of idealism with contemporary continental philosophy of religion (see Nenon 2013), but rather with the origins of analytic philosophy as such. By the time analytic philosophy of religion took off, $^{5}$ idealism had already been outright rejected by the early analytic

3 Wolter: "Scotus objects to [Aquinas' view that the future and past is coextensive with eternity] because the future precisely qua future is non-existent now and just as God's omnipresence does not extend to non-existent places, so neither does the 'now' of God's eternity coexist with the as yet non-existent future. Scotus objects to [Bonaventure's view that God knows the future through the ideas of creatures] because ideas are in the divine intellect prior to any creative decision on the part of his will." (Wolter 1990, 288)

4 Though there is some evidence of renewed interest in idealism as can be seen from (Goldschmidt and Pearce 2017a; Ward 2017; Farris, Hamilton, and Spiegel 2016).

${ }^{5}$ Hasker: "Analytic philosophy of religion was gestated in the 1940s, born in the 1950s, spent its childhood in the 1960s and its adolescence in the 1970s and early 1980s." (Hasker 2008, 421) 
philosophers, who have, in large part, defined themselves in opposition to the trend of British Idealism. This specifically historical constellation has led to a marginalisation of idealism as somewhat of a curiosity, squeezed in between materialism and dualism despite there being, in fact, no "serious reason[s] for regarding idealism as less viable than dualism or materialism." (Goldschmidt and Pearce 2017b, ix)

Nevertheless, the tide seems to be turning - idealism, both of the Kantian, and the Berkeleyan variety, has begun to receive interest from analytic philosophers. ${ }^{6}$ In what follows, I will apply some tenets of idealism to the problem of time and eternity raised by Aquinas and Scotus. I will not defend idealism. I will merely want to show that if idealism (or rather, one of its varieties which I describe below) is accepted, the problem in Aquinas and Scotus can be resolved.

\section{Partial Idealism}

Before going further, let us start with some definitions from the article on the Stanford Encyclopedia by Guyer and Horstmann, who distinguish between two different types of idealism:

(1) "Metaphysical" or "Ontological" Idealism: "Something mental (the mind, spirit, reason, will) is the ultimate foundation of all reality, or even exhaustive of reality, ...."

(2) "Formal" or "Epistemological" Idealism: "Although the existence of something independent of the mind is conceded, everything that we can know about this mind-independent 'reality' is held to be so permeated by the creative, formative, or constructive activities of the mind (of some kind or other) that all claims to knowledge must be considered, in some sense to be a form of self-knowledge." (Guyer and Horstmann 2018)

Guyer and Horstmann classify Berkeley as holding the first of these views and Kant as holding the second. For the purposes of this paper, I will leave "formal" or "epistemological" idealism aside, and stipulate that ontological idealism about time is correct.

Notice that each one of these two positions can further be refined by limiting the particular type of idealism in question to be an idealism about something, just like one can be a realist about certain aspects of reality and an idealist about others. In my case, let us limit the idealist position to time. We get:

\footnotetext{
${ }^{6}$ "One might even get the impression that in contemporary scientifically-oriented philosophy idealism is no longer considered a threat. The way in which in current discussions in the philosophy of mind some idealistic conceptions under the general name of 'panpsychism' are taken seriously (Nagel, Chalmers) seems to be a good indicator of this tendency." (Guyer and Horstmann 2018)
} 
Ontological idealism about time (OIT): "Something mental (the mind, spirit, reason, will) is the ultimate foundation of time, or even exhaustive of time."

OIT is thus a smaller-scale idealism, an idealism about a segment of reality, not about reality as a whole. Although the aim of this paper is simply to assume OIT and then see how it impacts the Aquinas-Scotus conundrum, here are at least a few reasons why one might think it is not as counter-intuitive as it may initially seem:

First, notice that at the deepest level, the mind provides us with an immediately accessible stream of mental states in which memories of past states are retained and included in those that follow; this stream of states in our mind directly accessible by phenomenology seems to instantiate temporal passage. That is, once we posit a mind, the existence of temporal passage seems inevitably to follow. Of course, this does not mean that there is temporal passage in the external world: the temporal passage in the mind might still be an illusion (see Hoerl 2014; Baron et al. 2015). But the illusion itself is temporal: "[S]ince the phenomenal is the realm of appearance, if experience seems to exhibit flow and passage, it does." (Dainton 2000, 178)

Second, apart from giving us an immediate experience of change, the mind, in virtue of being the seat of memory, furnishes the synthesis required for the retention of past moments of time in the external world, thus providing the "glue" holding together successive temporal moments, thereby grounding the existence of temporal extension. It seems like without the human mind, reality would merely exist as a series of disconnected slices or fragments (see Fine 2005). Consider the following example by R. P. Wolff:

When I count a row of twelve stones, I look at the first one and say "one." Then I look at the second, think of the first, and say "two" ... The process is repeated up to "twelve," at which time I am aware of myself as having performed a series of connected acts. If I merely found myself saying "twelve" after a while, or if I could recall previous utterances of "one," etc., but didn't recognize them as the earlier stages of a single activity whose culmination was the "twelve," then I could not know that I had just counted twelve objects. (Wolff 1968, 116; see also Bardon 2010, 69)

Third, it does seem like the connection between the mind and time is much stronger than between the mind and other features of reality, e.g., (minddependent) colours or spatial extension. There seems to be something "special" about time. There is nothing obviously contradictory in conceiving a world with, say, only two dimensions, a world without colours, a world where objects have 
no mass or a world with no space at all. However, even the one-dimensional character in Abbott's Flatland still displays activities characteristically connected to time (he speaks for example) (Abbott 1884). An analogy will help to clarify this. If we replace all people in the universe with colour-blind individuals, it no longer seems to make sense to speak of colours "existing" in that universe at all. What would "exist" in that world is a "something" which, when placed in contact with a non-colour-blind human mind, becomes "colour." Nevertheless, temporal objects (now colourless) would still continue to exist; all other familiar features of reality (objects' mass, spatial extension, laws of nature etc.) would continue to exist. Similarly, the representations of colours, conceived by the colour-sensitive minds before their disappearance from that world, would still continue to exist (e.g., words "green," "red" and blue would still be written on the pages of colourless books), although they would now probably make very little sense to the colour-blind individuals. By contrast, if we remove all minds simpliciter from the universe, it no longer makes sense to speak of any unified temporally extended object as "existing" in that universe. Without time-sensitive individuals, the picture of that world becomes completely incoherent; the temporal extension of objects would disappear and with them the idea of a unified "object" altogether. Reality becomes fragmented into disconnected slices.

In other words, the set of features that characterise any object (its qualia, temporal extension or location, mass, chemical composition, spatial extension or location, origin etc.) does not appear to be like a fence with wooden planks, some of which may be removed without the fence falling. It is more like a bridge; some of its parts may be removed with the bridge still standing (albeit with missing railings or unsafe for cars to drive over it). But there are some parts of it such that, when removed, they cause the bridge to fall and to stop existing qua a bridge. I have stipulated that time is one of such parts, but, naturally, there may be others. Kant certainly thought so. Of course, as I mentioned earlier, my aim here is simply to posit OIT and not provide its defence; but the reasons above should hopefully demonstrate that the view is not completely counter-intuitive.

\section{Temporally Extended Reality}

The previous section concluded with the observation that if we presume OIT is correct, the temporal extension of objects depends for its existence on the human mind. Or in other words, it entails that temporally extended objects should be considered as a "compound" of the ontological temporal glue provided by the synthesising mind-and of something else. In this section, I will show that this "something else" should be thought of as divinely-created timeless esse. 
The central metaphysical presupposition of the entirety of Aquinas' theological system is the claim that all things are dependent for God on their being. Specifically, Aquinas argues that:

The second [way things are kept in existence] is a per se and direct way of preserving a thing in existence, insofar, namely, as the thing preserved is so dependent that without the preserver it could not exist. This is the way that all creatures need God to keep them in existence. For the esse of all creaturely beings so depends upon God that they could not continue to exist even for a moment, but would fall away into nothingness unless they were sustained in existence by his power ... (Aquinas 1975b, 14. Divine Government (Ia2ae.103-9):IaQ104a1)

For other [i.e., non-divine] agents act as existing externally: since they do not act except by moving and altering a thing qualitatively in some way with respect to its exterior, they work from without. But God acts in all things from within, because he acts by creating. Now to create is to give existence (esse) to the thing created. So since esse is innermost in each thing, God, who by acting gives esse, acts in things from within. (Aquinas 2010, Chapter 1, Lecture 5, no. 133)

I suggest that we think of divine creation in timeless terms. God provides timeless esse, which is synthesised by the human minds instantiating temporal passage. For any temporally extended object or event two things need to come together "simultaneously" (i) the creative activity of God that eternally provides individual moments of time and (ii) the human mind which synthesises these moments. It is in conformity to the human mind that the temporally extended object or event is born.

However, how should we describe the "other" part of the compound, the timeless "stuff" that originates in God? One option is to answer this question in a Kantian way. Perhaps we are completely ignorant about what it exactly is that God creates. God is the timeless ontological foundation of everything in reality and our access to everything He creates is so inescapably temporal that there is very little we can say about his creative activity itself (see for example Pieper and Wieck 1953); we are merely left with having to affirm that, once the divine creative activity has happened (e.g., once we remember having looked at the apple on the table a second ago), we recognise that it has taken place, i.e., we realise that our mind has synthesised bits of being to form a temporally continuous object that is now retained in our memory.

Although the mystery of what is happening in the present of divine creative activity is in a sense partially inaccessible to us, there are nevertheless more things we can say about the machinery of divine creation and its relation to our mind. We may describe the situation as follows: For every particular interval of 
spacetime, God is recognised as being the source of its existence. ${ }^{7}$ This would be true even if there were no humans. However, for a set of these points to exist as an extended unified object (as opposed to being a series of disconnected fragmented positions), it needs to be synthesised by the mind. We do not perceive instants of time, only God can do this since his creative and sustaining activity extends even to subatomic particles.

\section{Relative Realities}

How does bifurcating bits of reality into the mind-dependent temporal extension and God-dependent timeless being resolve the problem raised at the beginning of this paper?

Let us start by recalling that the Aquinas/Scotus discussion seems to push the theist to accept two incompatible positions about temporal ontology: presentism and eternalism. Furthermore, observe that eternalism coheres quite well with the presence of all things to eternity (see Mellor 1986) - if everything exists, then all can be present to God - and has standardly been taken to be the ontological position most compatible with the special theory of relativity (see Rietdijk 1966; Putnam 1967). By contrast, presentism seems to be highly compatible with temporal passage, but incompatible both with relativity and the presence of things to eternity. Can OIT offer a way to bring these two together?

According to the special theory of relativity, simultaneity and succession cannot be extended as absolute relations throughout the universe, but may only be limited to a particular frame of reference. That is, one cannot meaningfully answer questions of the form "Is $\mathrm{x}$ simultaneous with $\mathrm{y}$ ?", but only questions of the form "Given a particular reference frame, is x simultaneous with $\mathrm{y}$ ?" The

\footnotetext{
${ }^{7}$ By way of limitation, I leave aside the questions pertaining to the problem of "empty times" and "empty spaces," i.e., questions whether it is possible for a time or space without anything in it to exist. Aquinas argued that since time is connected to movement and movement must be created by the First Mover, time (as well as space) is only possible where some sort of creation (i.e., giving being to things) has already taken place. See for example: "[O]utside the entire universe of creatures, there is no time, time having been produced simultaneously with that universe; hence, we do not have to look for the reason why it was produced now and not before, so as to be led to concede the infinity of time; ... ." (Aquinas 1975a, II.35.6) This, of course, brings us back to the Leibniz-Clarke dispute about the relationship of things to time, which I do not have space to discuss here. The potential existence of these "empty spaces" would, of course, be a problem for divine omnipresence. Space does not permit me to discuss this problem here, but two things should be said: the first is that the problem may simply be dealt with by stipulating that even an empty place has "being of some sort" and must, therefore, have been created by God. The second is that the matter cannot be resolved without a full discussion of the difference between "place" and "space" in Aquinas' usage; the notion of "space" (locus) which Aquinas takes over from Aristotle does not map directly onto "(a bit of) space" as analytic philosophy understands it.
} 
relativity of the ordering of events (already rather problematic for the A-theorist) poses a particular ontological problem for the presentist, which Miller summarises as follows:

[S] uppose that John and Bert co-exist, that is, each judges the other to be simultaneous with himself. Suppose that according to Bert, Mary co-exists with Bert. Suppose existence is transitive - if $x$ co-exists with $y$, and $y$ co-exists with $z$, then $x$ co-exists with $z$. Then it follows that John co-exists with Mary. But it is consistent with all that we have said that from John's frame of reference, Mary does not co-exist with John but instead Mary is located earlier, or later, than John. So if John is committed to Mary's existence, then he is committed to the existence of objects that are not, relative to his frame of reference, in the present. Since we can set up long chains of observers located in different frames of reference, we can derive the conclusion that John ought to be committed to the existence of objects he takes to be very distantly located in the past or future, and likewise for all the other observers in the chain. (Miller 2013, 352; see also Rietdijk 1966; Putnam 1967)

Contrary to the seemingly inevitable inference from relativity to eternalism implied by Miller, there is another, more exciting option, namely to framerelativise or space-point-relativise existence. Miller briefly considers this possibility:

[I]t can be argued that what we have learned from [the] S[pecial] T[heory of] R[elativity] is that all talk should be frame-relativized, and therefore that talk of existence and co-existence ought to be frame-relativized. ... The idea that existence itself is not transitive is counterintuitive. It is, after all, the idea that although $X$ exists relative to Peter, and Peter and Bert exist relative to one another, nevertheless X does not exist relative to Bert. (Miller 2013, 354)

I consider this option regardless of its counter-intuitiveness. A full elaboration of this possibility has been provided by Dorato's Time and Reality (Dorato 1995). Dorato argues that once spacetime points are understood not purely epistemically or semantically, but ontologically, we can place the weight of relativizing ontological qualifications about existence and non-existence onto them, thus not necessarily following the inference from relativity to eternalism. We thus end up with what Robin Le Poidevin has fittingly captured in a review of Dorato's book as "relative realities" (Le Poidevin 1997). 8

Once again, I do not have space to defend the frame-relativisation of existence here, but it should be noted that Dorato-style spacepoint-relativisation has been rather unfortunately completely neglected by philosophers of religion discussing

\footnotetext{
8 It is worth noting that Le Poidevin, in the end, rejects Dorato's view.
} 
the ontological problem raised by Aquinas and Scotus, despite the fact that Dorato's view offers several ways of squaring presentism in the temporal realm and eternalism in the eternal realm.

One way of doing this is the one I offer here, namely, by observing that Dorato's view coheres perfectly with OIT. Recall that OIT implies that temporally extended objects or events depend partially on the human mind. This means that the existence of temporally extended objects is relative under two aspects; the first is that it is relative insofar as the objects depend for their non-synthesised non-temporal being on God, relatively to whose will, of course, everything exists, the second is that their temporal extension is relative insofar as it is indexed to a particular human mind which performs the synthesis of their non-temporally extended features at particular intervals (i.e., continuous sets of points) in spacetime. In the same way that the key question of presentism consists of asking "Does x exist [now]?" and of eternalism "At which part of the spacetime block does $x$ exist?," the frame-relativizing of existence leads us to ask "Whom does $x$ exist for?" In the case of God, the answer is "yes" to everything, since He is the creative cause for every particular " $x$," in the case of humans, the answer depends on the particular instance of the human mind performing the synthesis required for the existence of a given temporally extended object.

One can already begin to see how OIT makes it possible to be an eternalist and a presentist about reality, thus turning the dichotomy between Aquinas and Scotus into a false one: reality is divided into that bit that depends for its existence on the quasi-presentist mind instantiating temporal passage, and that bit which depends for its existence on the timeless God to whom all things are eternally present. The division of temporal and non-temporal aspects of created objects and the subsequent indexication of the former to temporal creatures and the latter to the eternal Creator allows one to have the presentist cake while eating the eternalist one too. First, on the temporal side, the presentist picture coheres with our immediate intuitions and experience about temporal passage, while the relativizing of these presents to individual human observers coheres conceptually with the special theory of relativity. Second, on the eternal side, the non-temporal eternally created being coheres perfectly with divine eternal creative knowledge of the world. One, therefore, does not need to abandon either presentism or the relativity of simultaneity (which seems, unlike in Aquinas' day, unabandonable)-or indeed an eternal presence of things to eternity. Each ontology is simply relativised to a different realm.

Naturally, the questions about OIT and Dorato's "relative realities" are orthogonal: the presentist is not committed to Dorato's views. What I argue for here is that if one wishes to affirm that presentism is true for human minds and eternalism is true for God, then they need something like OIT - and that Dorato's "relative realities" demonstrate how OIT can be connected to the strand of 
discussions about relativity, eternalism, and eternity, which the presentist would need to incorporate. Although most medieval philosophers were presentists, post-Einstein we know that maybe they should not have been.

Before moving further, let us summarise the discussion so far. I have started by observing an incompatibility between temporal passage and the eternal presence of things to God. I then stipulated OIT, which allowed me to separate reality into two realms: the temporally extended and the timeless divinelycreated esse. I then showed that OIT not only allows us to hold together temporal passage (though merely "in the head") and eternal presence of things to God, but also-via Dorato's relative realities-offers ways of incorporating ontological questions arising from the special theory of relativity.

\section{Causation of Esse}

Before turning to objections, it is worth observing that my view is deeply consonant with a recent repositioning of the picture of the dependence of things on God in analytic philosophy.

As far back as the 1990s, Brian Shanley, in an engagement with Stump and Kretzmann, observed that the dependence of things on God is one of the most overlooked facets of the God-time relation as it is articulated in analytic philosophy (see Shanley 1998b; 1998a; 1997). Too much emphasis on the talk of God "seeing things" merely perpetuates the picture of God as a detached "big viewer." This picture, Shanley argues, not only illegitimately separates God's creative action in the world and His knowledge of it, ${ }^{9}$ but also generates the type of problems raised by Scotus. When observing the analytic appropriations of Aquinas' thought, one sees this implicit picture resurface again and again. Thus, for example, Craig argues that "God ... does not experience events successively as past, present, and future, as we do; rather the whole time line, if you will, is stretched out before Him" (Craig 1985, 478)-implying that the relation of God to His creation is similar to that of our own experience of looking at external reality stretched out in space before us. This way of thinking about the Godworld relation is also implicit in most of the analytic attempts at articulating divine timelessness (see for example Mellor 1986, 73-75; Padgett 2011, 120-23; Goris 2005, 106-8), especially those that conceive of the relation along the lines of different "frames of reference" (Leftow 1990, 390-93) in the case of Leftow and Stump \& Kretzmann's ET-Simultaneity (Stump and Kretzmann 1981). Leftow's attempt at conceiving of God's knowledge as "immediate," i.e., as opposed to depending on time-lagging causal signals (Leftow 1991, 169) further perpetuates

\footnotetext{
9 Shanley: "There is no mental process whereby God first speculatively considers the various possibilities, ... then practically decides to execute one plan ... and finally contemplates the finished product." (Shanley 1997, 217)
} 
the picture of things existing independently that God must somehow find a way to know as best as He can.

Instead, Shanley argues for what he calls God's "causal knowledge" (Shanley 1998a). God works in the temporal realm not purely as a formal and efficient cause; His primary causation is that of esse (Shanley 1998b, 104-5). "Scientia Dei est causa rerum." (Shanley 1997, 205; Aquinas 2012, IaQ14a8; 1952, Q2a14). Instead of both the metaphor of the mountain-top and that of the circle and its circumference, a more appropriate model to think of the knowledge that the Creator has of the temporal realm, a model which overcomes the overly "representationalist" picture of divine knowledge (Shanley 1998a, 455), is the relationship between the artist and the knowledge they have of their work - a model used by Aquinas himself - with the important clarification that the artist merely knows the form of the artwork they create, but not its matter, since it only belongs to God to be the cause of matter (Aquinas 1980, 1:I:Id38Q1a3, ad 1).

This Shanley-type view of the dependence of things on God seems to be growing in popularity in recent analytic philosophy. Thus, for instance, Matthews Grant uses God's universal causation of esse to develop a model of omniscience and libertarian freedom (Matthews Grant 2019) and a causal account of omniscience can also be found in Katherin Rogers (see Rogers 2007) or David Burrell (see Burrell 1993). This turn to esse is particularly important for motivating the philosopher of religion to find ways to defend OIT since OIT offers ways of connecting these strands of thinking about the God-time relation (by moving away from the "big viewer" picture) to our immediate experience of temporal passage and discussions about ontologies entailed by physics.

Perhaps tentatively, I would also suggest that something akin to OIT (though, of course, not to idealism simpliciter) may be found in Aquinas himself. Due to Aquinas' Aristotelian heritage, one finds a description of the relation between the perfecting of time in the mind, which is perfectly compatible with what has been argued for in the section above. Aquinas' ontology utilises a distinction between three types of objects, which John Wippel categorises as follows:

One type enjoys complete and total being outside the mind; that is, independently from the mind's consideration, ... such as human beings or stones. A second type enjoys no reality in itself independently from the mind, for instance, dreams or chimeras. A third kind has a foundation in extramental reality, but depends upon the intellect's operation for its complete realization. As illustrations Thomas cites universals and time. Each of these enjoys some foundation in extramental reality; but that which makes time to be time, or a universal to be universal, depends upon an intellectual operation. (Wippel 1989, 296) 


\title{
MATYÁŠ MORAVEC
}

A good example of this is the Commentary on the Sentences, where Aquinas provides more details on this third type of thing:

\begin{abstract}
[These things] possess a foundation in a thing outside of the soul, but that which completes their definition from a formal point of view, is an operation of the soul, as we can see in the case of the universal. Humanity, [for example], is something in reality, but it is not there where it has a ratio of a universal, because there does not exist outside of the soul a humanity common to a plurality of individuals; but according to the way that it is received in the intellect, an intention is added to it by an operation of the intellect in virtue of which it is called a species; and the same is the case for time, which has a foundation in movement, namely that it is the before and after of movement, but as regards that which is formal concerning time, namely the fact of counting it, it is accomplished by an operation of the intellect which counts. ${ }^{10}$
\end{abstract}

The view that time is somehow dependent on the human mind may seem to be contradicted by what Leftow observes about Aquinas' writings in the Commentary on Aristotle's Physics, where Aquinas argues that the passage of time has a foundation in extramental reality since it depends on the motion of the heavenly spheres, which exist independently of the human mind (Leftow 1990, 388). For instance, in $\S 573$, Aquinas says that time's flow cannot be "consequent upon the motion of the soul" (Aquinas 1963, IV.17, §573). This seems to be contradicted by the quotation from above. The two texts, however, do not necessarily stand in tension, since in commenting on and following Aristotle, Aquinas distinguishes between movement and time (as the number of movement). That is why he, like Aristotle, distinguishes movement as being a part of mindindependent extramental reality and depending on substance, and time (as the number of "before and after"), which, although it depends on this very movement, requires the human mind for its completion. This distinction runs throughout \$572-581 of the Commentary. To give just one example:

But when we take a before and after and number them, then we say that time passes. This is so because time is nothing else than the number of motion in respect to before and after. For we perceive time, as was said, when we number the before and after in motion. Therefore, it is clear that time is not motion, but is

10 "Quaedam autem sunt quae habent fundamentum in re extra animam, sed complementum rationis eorum quantum ad id quod est formale, est per operationem animae, ut patet in universali. Humanitas enim est aliquid in re, non tamen ibi habet rationem universalis, cum non sit extra animam aliqua humanitas multis communis; sed secundum quod accipitur in intellectu, adjungitur ei per operationem intellectus intentio, secundum quam dicitur species: et similiter est de tempore, quod habet fundamentum in motu, scilicet prius et posterius ipsius motus; sed quantum ad id quod est formale in tempore, scilicet numeratio, completur per operationem intellectus numerantis." (Aquinas 1980, 1:I:Id19Q5a1, my translation) 
consequent upon motion insofar as it is numbered. Hence time is the number of motion. (Aquinas 1963, IV.1, §580)

These resemblances are, of course, not meant to suggest that OIT itself may be found in Aquinas. Rather, I want to point out that if one draws a continuum of views from time being completely mind-independent (and contemporary analytic philosophy of time is clearly committed to the claim that answers to questions regarding the nature of time must be mind-independent) to OIT, Aquinas would find himself closer to the OIT end of the spectrum. Any analytic Thomist wanting to squeeze Aquinas through the meshes of relativity theory would have to bear this in mind.

\section{Objections}

The first objection against my view runs as follows. If I have adopted a presentist framework in the temporal realm, where can we locate truth-makers that ground the truth of facts about the past? For instance, on the standard eternalist picture, the proposition "Napoleon died in 1821" is made true-amongst other thingsby the person Napoleon and his death, both of which are said to exist in the spatiotemporal block simpliciter. It seems strange to have to ask whom these events exist for, presumably getting a different response in the case of Napoleon's contemporaries and in the case of people living in the year 2100. There are three already available ways out of this conundrum, none of which is specific to my position, but one that the OIT idealist may conveniently employ. The first is to switch to something like a "local idealist growing-block" theory of time; our mental content in virtue of which we synthesise the eternally-created positions includes both our present and our past. The death of Napoleon is in my past (either in virtue of my having remembered it or in virtue of the existence of testimony which exists for me) and the event recounted by that event therefore also exists for me. The second solution is simply to use the already-available presentist framework for dealing with the truth-maker problem by locating the truthmakers in a particular given present (see for example Bigelow 1996). The third solution is to ground the truths in the atemporal realm. This by no means requires going for "ersatz" presentism (see Crisp 2007), since the inclusion of God in my theory of time comes with a pleasant bonus: the traditional Christian claim that all truths depend eternally on God for their being (see Schultz-Aldrich 2009; Wippel 1989; 1990; Wood 2013; van Becelaere 1903; Moravec forthcoming); the truth of the proposition "Napoleon died in 1821" is made true by God eternally creating such a state of affairs.

The second objection, related to the one from above, could be formulated as follows: How does my theory deal with sections of the spacetime block that are 
not present to anyone? Do bits of evolutionary history or things that Martians will one day set up in a distant galaxy exist? Although this riposte looks coherent on the face of it, it receives its primary force from smuggling in the notion of absolute existence in time, which my account rejects. The question about Martians is not well-formulated and should instead be posited as follows: "Whom do bits of evolutionary history or things that Martians will one day set up in a distant galaxy exist for?" For us, the question regarding bits of evolutionary history can be dealt with using the response to the previous objection, i.e., by reiterating that the past (qua past simpliciter or qua memory) exists for us. For us, the question regarding Martians' settlements is simply in the negative, although it may be positive for the Martians, should they have minds sophisticated enough to synthesise time. And finally, if both have been or will be created by God, they exist for Him; there is no "section of the spacetime block that is not present to anyone." This also means that temporal extension does not exist before synthesising minds come into the picture - at the beginning of creation, all things are timelessly present to God, but temporal passage does not exist. But this is not as strange as it might initially seem - it is merely analogous to the claim that colours did not exist before the human eye (which processes rays of lights as colours) did. Individual "moments" existed present in the mind of God. But for these to be synthesised into temporal extension, human minds had to be created.

The third objection is the following: How can we explain the fact that the individual idealist temporal perspectives are all so well coordinated? For example, how is it that the temporal objects synthesised by my mind in this section of the spacetime block correspond so well to someone else's and that they are both governed by the same laws of nature? It may be said that by inviting idealism into our ontology, we have also invited the related Berkeleyan problem about the objectivity of truth. Indeed, one of the advantages of stipulating an eternalist spacetime block in which everything exists simpliciter is that it provides an answer to the mutual co-ordinations of different perspectives on it; the block may not contain an objective present, a unique plane of simultaneity, a separation between past, present, and future etc., but it still has the same events in it, the same time-order (before-or-simultaneous-with is a relation transferrable from one pair of events to another), and its contents are governed by the same laws. We have lost this benefit by getting rid of the absolutely existing spacetime block as such. There are, fortunately, two ways to respond to this problem: The uninvited Berkeleyan guest can be removed using a Berkeleyan move; for Berkeley, the objectivity of truth is guaranteed by the role that God plays in his metaphysical system. The same is true in our case; we can make the theological move of appealing to divine benevolence to affirm that all the eternally created being is created by God such that it is coherently governed by perfectly coordinated laws of physics. The other option of responding to this is by evading 
the question altogether by observing that the relativization proposed above merely concerns the existence of bits of the spacetime block, not its order, arrangement, and relations - the two are rather different questions. The laws of physics can still be coherent independently of the existence of the things they govern, in the same way that there can be a coherent seating order at a dinner party ensuring no two guests are sitting in two seats (or vice versa), regardless of whether anyone actually turns up. ${ }^{11}$

The final objection may be stated as follows: If the nature of time depends partially on God and partially on humans, why can God not be responsible for the features of time that I have made humans responsible for? The answer here is that God is responsible for these features, albeit indirectly-God creates the human minds, which then synthesise moments of time. Here the analogy with colours, discussed above, is helpful once again. If the perception of colours is grounded in the properties of external objects and yet requires the human mind for the colours to be fully realized, what does it mean to say that God cannot create, for instance, a red object? I discussed a similar example in an earlier paper by appealing to Kripke's example of the epistemological and ontological relations between "molecular motion," "heat," and "sensation of heat." (Moravec forthcoming) Kripke asks, does God need to do anything additional in order for "molecular motion" to be "heat"? It seems that He does not: in the act of creating molecular motion, He creates heat. What He additionally needs to do is to arrange for "molecular motion" to be felt as "sensation of heat" by human beings. The situation here is rather similar. For God to create a particular object which exists in objective time, He merely needs to create whatever it is that may retrospectively be recognised by human beings as the four-dimensional spacetime worm existing in the B-structure. However, for this to be a temporally extended object, He needs to create humans with a synthesising mind in order for them to recognise the object as such. ${ }^{12}$

\section{Conclusion}

${ }^{11}$ Another way of making this coherent is by adopting an absolutist perspective on time and temporalist perspective on God and going for what Mullins calls the "Identification" view of the God-time relation. On this view, which Mullins ascribes to Oresme, time is an attribute of God: God is the ontological source of moments and is responsible for their ordering and the direction of causation (Mullins forthcoming).

12 The position advocated here is one of "partial" co-operation in creating the effect: God provides the timeless esse, the human mind provides the temporal extension. Matthews Grant provides an analogy to show how both causes can contribute wholly to an effect: "Tolkien brought it about [in The Hobbit] that Smaug died by means of an arrow shot from Bard's bow, but the dragon and the archer, the bow and the arrow, and everything else in the story are with the same immediacy dependent on Tolkien." (Matthews Grant 2019, 38) 
The foregoing discussion may be read in two different directions. I have started by stipulating OIT and showing how it can resolve the problem of incompatible ontologies in Aquinas and Scotus and that OIT in fact offers a way of incorporating discussions regarding relativity into the debate without sacrificing Aquinas' commitment to temporal passage. The argument, however, may be read in reverse, namely, by pointing out that a commitment to relativity, divine timelessness, and temporal passage requires OIT as a missing piece of the puzzle to make the whole thing work. I am hoping this argument will further motivate the analytic philosopher of religion to get on the train of growing interest in idealism. $^{13}$

\section{Bibliography}

Abbott, Edwin. 1884. Flatland. A Romance of Many Dimensions. London: Seeley \& Co.

Aquinas, St Thomas. 2012. Summa Theologiae. Translated by L. Shapcote. Lander: The Aquinas Institute for the Study of Sacred Doctrine.

Aquinas, St Thomas. 2010. Commentary on the Gospel of John. Translated by Fabian Larcher and James Weisheipl. Washington, D.C.: The Catholic University of America Press.

Aquinas, St Thomas. 2009. Compendium of Theology. Translated by Richard J. Regan. New York: Oxford University Press.

Aquinas, St Thomas. 2003. On Evil. Translated by Richard Regan. New York: Oxford University Press.

Aquinas, St Thomas. 1980. In Quatuor Libros Sententiarum. Vol. 1. Opera Omnia. Friedrich Fromann: Stuttgart-Bad Cannstatt.

Aquinas, St Thomas. 1975b. Summa Theologiae. Translated by T. C. O'Brien. Vol. 14. Divine Government (Ia2ae.103-9). London: Blackfriars.

Aquinas, St Thomas. 1975a. Summa Contra Gentiles. Translated by J. F. Anderson. First edition. Notre Dame and London: University of Notre Dame Press.

Aquinas, St Thomas. 1964. Summa Theologiae. Translated by Thomas Gornall. Vol.

4. Knowledge in God (Ia.14-18). London: Blackfriars.

Aquinas, St Thomas. 1963. Commentary on Aristotle's Physics. Translated by Richard J. Blackwell, Richard J. Spath, and W. Edmund Thirkel. London: Routledge \& Kegan Paul.

${ }^{13}$ I am grateful to Robin Le Poidevin, Ryan Mullins, anonymous reviewers of TheoLogica and participants of the God and Time III workshop (University of Lugano, 23-24 $4^{\text {th }}$ August 2019) for comments on earlier versions of this paper. The writing of this paper was supported by funding from a studentship hosted by the Cambridge Arts and Humanities Research Council Doctoral Training Partnership and Pembroke College, Cambridge (Grant Number: AH/L503897/1, Grant Recipient: Matyáš Moravec). 
Aquinas, St Thomas. 1952. The Disputed Questions on Truth. Translated by Robert W. Mulligan. Chicago: Henry Regnery Company.

Bardon, Adrian. 2010. "Time-Awareness and Projection in Mellor and Kant." Kant-Studien 101 (1): 59-74. https://doi.org/10.1515/kant.2010.004.

Baron, Samuel, John Cusbert, Matt Farr, Maria Kon, and Kristie Miller. 2015. “Temporal Experience, Temporal Passage and the Cognitive Sciences." Philosophy Compass 10 (8): 560-71. https://doi.org/10.1111/phc3.12244.

Becelaere, F. L. van. 1903. "Summary Exposition of Saint Thomas Aquinas's Philosophy of Knowledge." The Philosophical Review 12 (6): 611-28. https://doi.org/10.2307/2176980.

Bigelow, John. 1996. "Presentism and Properties." Philosophical Perspectives 10: 35-52. https://doi.org/10.2307/2216235.

Boethius. 1973. The Consolation of Philosophy. Translated by S. J. Tester. Cambridge, Massachusetts: Harvard University Press. https://doi.org/10.4159/DLCL.boethius-consolation philosophy.1973.

Burrell, David B. 1993. Freedom and Creation in Three Traditions. Notre Dame: University of Notre Dame Press.

Craig, William Lane. 1985. “Was Thomas Aquinas a B-Theorist of Time?" The New Scholasticism 59 (4): 475-83. https://doi.org/10.5840/newscholas19855946.

Crisp, Thomas M. 2007. "Presentism and the Grounding Objection." Noûs 41 (1): 90-109. https://doi.org/10.1111/j.1468-0068.2007.00639.x.

Dainton, Barry. 2000. Stream of Consciousness. Unity and Continuity in Conscious Experience. London: Routledge.

Dorato, Mauro. 1995. Time and Reality: Spacetime Physics and the Objectivity of Temporal Becoming. Bologna: Cooperativa Libraria Universitaria Editrice Bologna.

Farris, Joshua R., S. Mark Hamilton, and James S. Spiegel, eds. 2016. Idealism and Christian Theology. New York: Bloomsbury.

Finance, Joseph de. 1956. "La présence des choses à l'éternité d'après les scolastiques." Archives de Philosophie 19 (2): 24-62.

Fine, Kit. 2005. "Tense and Reality." In Modality and Tense: Philosophical Papers, 261-320. New York: Oxford University Press. https://doi.org/10.1093/0199278709.003.0009.

Goldschmidt, Tyron, and Kenneth L. Pearce, eds. 2017a. Idealism: New Essays in Metaphysics. New York: Oxford University Press.

Goldschmidt, Tyron, and Kenneth L. Pearce. 2017b. "Introduction." In Idealism: New Essays in Metaphysics. New York: Oxford University Press.

Goris, Harm. 2005. “Divine Foreknowledge, Providence, Predestination, and Human Freedom." In The Theology of Thomas Aquinas, edited by Rik Van Nieuwenhove and Joseph Wawrykov, First edition, 99-122. Notre Dame: University of Notre Dame Press. https://doi.org/10.2307/j.ctvpj7g49.11. 
Guyer, Paul, and Rolf-Peter Horstmann. 2018. "Idealism." In The Stanford Encyclopedia of Philosophy, edited by Edward N. Zalta, Summer 2018. Metaphysics Research Lab, Stanford University. https:/plato.stanford.edu/archives/sum2018/entries/idealism/.

Hasker, William. 2008. "Analytic Philosophy of Religion." In The Oxford Handbook of Philosophy of Religion, edited by William J. Wainwright, 421-46. Oxford: Oxford University Press. https://doi.org/10.1093/0195138090.003.0018.

Hoerl, Christoph. 2014. “Do We (Seem to) Perceive Passage?" Philosophical Explorations 17 (2): 188-202. https://doi.org/10.1080/13869795.2013.852615.

Johnson, David Kyle. 2009. "God, Fatalism, and Temporal Ontology." Religious Studies 45 (4): 435-54. https://doi.org/10.1017/S0034412509990059.

Le Poidevin, Robin. 1997. "Relative Realities." Studies in the History and Philosophy of Modern Physics 28 (4): 541-46. https://doi.org/10.1016/S1355-2198(97)00020$\underline{8}$.

Leftow, Brian. 1990. "Aquinas on Time and Eternity." American Catholic Philosophical Quarterly 64 (3): 387-99. https://doi.org/10.5840/acpq199064315.

Leftow, Brian. 1991. Time and Eternity. Ithaca and London: Cornell University Press.

Matthews Grant, W. 2019. Free Will and God's Universal Causality. The Dual Sources Account. Bloomsbury Studies in Philosophy of Religion. London: Bloomsbury.

Mellor, D. H. 1986. "History Without the Flow of Time." Neue Zeitschrift Für Systematische Theologie Und Religionsphilosophie 28 (1): 68-76. https://doi.org/10.1515/nzst.1986.28.1.68.

Miller, Kristie. 2013. "Presentism, Eternalism, and the Growing Block." In $A$ Companion to the Philosophy of Time, edited by Heather Dyke and Adrian Bardon, 345-64. Malden, Oxford and Chichester: Wiley-Blackwell. https://doi.org/10.1002/9781118522097.ch21.

Moravec, Matyáš. Forthcoming. "Aquinas and Kripke on the Genealogy of Essential Properties." The Heythrop Journal. https://doi.org/10.1111/heyj.13045. Mullins, Ryan T. Forthcoming. "From Divine Timemaker to Divine Watchmaker." In Temporality and Eternity Ten Perspectives on God and Time, edited by Marcus Schmücker, Michael Thomas Williams, and Florian Fischer. De Gruyter.

Mullins, Ryan T. 2016. The End of the Timeless God. Oxford: Oxford University Press. https://doi.org/10.1093/acprof:oso/9780198755180.001.0001.

Nenon, Thomas, ed. 2013. Kant, Kantianism, and Idealism: The Origins of Continental Philosophy. Durham: Acumen. https://doi.org/10.4324/9781315729794.

Padgett, Alan G. 2011. "The Difference Creation Makes: Relative Timelessness Reconsidered." In God, Eternity and Time, edited by Christian Tapp and Edmund Runggaldier, 117-24. Farnham and Burlington: Ashgate. 
Pasnau, Robert. 2011. Metaphysical Themes 1274-1671. New York: Oxford University Press. https://doi.org/10.1093/acprof:oso/9780199567911.001.0001.

Pieper, Josef, and Fred Wieck. 1953. “On the 'Negative' Element in the Philosophy of Thomas Aquinas." CrossCurrents 4 (1): 46-56.

Putnam, Hilary. 1967. "Time and Physical Geometry." The Journal of Philosophy 64 (8): 240-47. https://doi.org/10.2307/2024493.

Rietdijk, C. W. 1966. "A Rigorous Proof of Determinism Derived from the Special Theory of Relativity." Philosophy of Science 33 (4): 341-44. https://doi.org/10.1086/288106.

Rogers, Katherin A. 2007. "God Not the Author of Sin: An Anselmian Response to McCann." Faith and Philosophy 24 (3): 300-310. https://doi.org/10.5840/faithphil200724314.

Schultz-Aldrich, Janice L. 2009. "Being as the Ground of Truth in Aquinas." The Heythrop Journal 50 (4): 620-34. https://doi.org/10.1111/j.14682265.2008.00453.x.

Scotus, John Duns. 1963. Ordinatio I. Vol. 4. Opera Omnia. Vatican: Typis Polyglottis Vaticanis.

Shanley, Brian J. 1998b. "Divine Causation and Human Freedom in Aquinas." American Catholic Philosophical Quarterly $72 \quad$ (1): 99-122. https://doi.org/10.5840/acpq19987216.

Shanley, Brian J. 1998a. "Aquinas on God's Causal Knowledge: A Reply to Stump and Kretzmann." American Catholic Philosophical Quarterly 72 (3): 44757. https://doi.org/10.5840/acpq199872330.

Shanley, Brian J. 1997. "Eternal Knowledge of the Temporal in Aquinas." American Catholic Philosophical Quarterly $71 \quad$ (2): 197-224. https://doi.org/10.5840/acpq199771244.

Stump, Eleonore, and Norman Kretzmann. 1981. "Eternity." The Journal of Philosophy 78 (8): 429-57. https://doi.org/10.2307/2026047.

Ward, Keith. 2017. The Christian Idea of God. A Philosophical Foundation for Faith. Cambridge: Cambridge University Press. https://doi.org/10.1017/9781108297431.

Wippel, John F. 1989. "Truth in Thomas Aquinas." The Review of Metaphysics 43 (2): 295-326.

Wippel, John F. 1990. "Truth in Thomas Aquinas, Part II." The Review of Metaphysics 43 (3): 543-67.

Wolff, Robert Paul. 1968. "A Reconstruction of the Argument of the Subjective Deduction." In Kant: A Collection of Critical Essays, edited by Robert Paul Wolff. Notre Dame: University of Notre Dame Press. 
Wolter, Allan B. 1990. "Scotus' Paris Lectures on God's Knowledge of Future Events." In The Philosophical Theology of John Duns Scotus, edited by Marilyn McCord Adams, 285-333. Ithaca and London: Cornell University Press.

Wood, William. 2013. "Thomas Aquinas on the Claim That God Is Truth." Journal of the History of Philosophy 51 (1): 21-47. https://doi.org/10.1353/hph.2013.0007.

Published Online: February 19, 2021 